\title{
透析患者と便秘
}

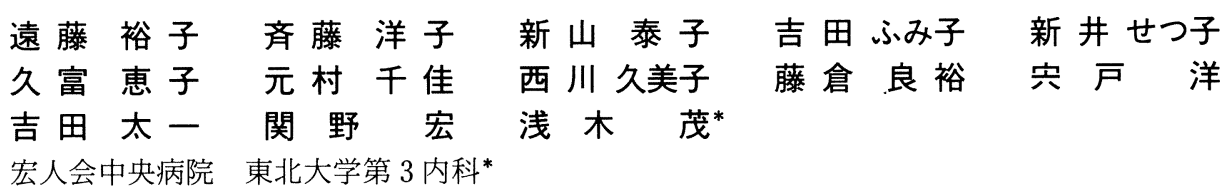

(昭和 58 年 9 月 8 日受付)

key words : constipation, hemodialysis, laxatives

〈要旨〉

便秘は精神的, 肉体的に不快なものである. 食生活を制限されている透析患者では, 従来より便秘を訴えることが 多く下剂服用者も多い, 私達は当院患者 124 名（男 70 名, 女 54 名）を対象とし, 排便の状況, 下剂の使用状況など について調査を行い,「透析患者と便秘一現状と対策一」について検討した。

下剤服用者と排便困難者を併せて便秘群とすると，便秘群は 52 名 (男 23 名，女 29 名) で全体の $42 \%$ 占めた。透 析導入とともに便秘に陥った患者が多く，水分制限，除水等の影響が大きいものと思われる.下剂は刺激性下剤の服 用者が多く, 実際効果的であった。 下剂使用が常用量を越す人に対して, 偽薬を処方することにより服薬量の減量が 可能であった。 また, 便秘解消法のパンフレットを作成し, 社会活動の勧め, 生活指導, 腹部マッサージや指圧, 繊 維性食品の食事指導などを行った。 その結果, 下剂服薬が必要でなくなった人が 13 名, 減量できた人が 21 名みられ た。透析患者の便秘には除水, 水分制限, 消化管運動機能低下, 薬物および精神的要因など複合的成因の関与が考え られる.

\section{Conspitation in hemodialysis patients}

Yuko Endo, Yoko Saito, Yasuko Niiyama, Fumiko Yoshida Setsuko Arai, Keiko Hisatomi, Chika Motomura, Kumiko Nishikawa, Yoshihiro Fujikura, M. D., Yo Shishido, M. D., Taichi Yoshida, M. D., Hiroshi Sekino, M. D. and Shigeru Asaki, M. D.*

Kojin-Kai Central Hospital., Third Department of Internal Medicine, Tohoku University School of Medicine*

Constipation is mentally and physically uncomfortable for hemodialysis patients. Many such patients complaining of constipation are placed on laxatives.

An attempt was made to evaluate the defecation and use of laxatives in 124 patients (70 males, 54 females) undergoing hemodialysis at Kojin-Kai Central Hospital. Physical management of constipation in hemodialysis patients was attempted.

Patients ingesting laxatives as well as those experiencing difficulty in defecation were judged as having constipation. Fifty-two (23 males, 29 females) of the 124 patients (42\%) were estimated as patients with constipation. Since many patients tended to have constipation after the introduction of hemodialysis, we considered that the constipation was influenced by restriction of water intake and removal of excess body fluid. In those patients, stimulative laxatives were widely employed and proved clinically effective.

It was sometimes possible to decrease the dosage of laxatives by the use of placebo in patients who had been on a high dose of laxatives. The patients were trained using a pamphlet on how to relieve constipation; for example, how to massage the abdomen, how to apply finger pressure and also how to ingest fibruus ingredients. As a result, laxatives were withdrawn in 13 patients and the dosage was reduced in 21 patients.

It may be concluded that constipation in hemodialysis patients in attributable to a complex set of factors, such

遠藤 裕子 宏人会中央病院

干 980 仙台市東七番丁 84 （0222-97-6211） 
as restriction of water intake, removal of excess body fluid by hemodialysis, dysfunction of the digestive tract, adverse effects of other drugs and also mental conditions.

\section{緒言}

便秘は私達健康人にとっても精神的，肉体的に不快な ものである．食生活を制限されている透析患者では従来 より便秘を訴えることが多く ${ }^{1,2)}$ ，下剤服用者も多い。そ こで私達は当院患者を対象として，アンケートを主とし た調査を行い「透析患者と便秘」についての現状と, 便 秘に対する対策を検討したので若干の考察を加え報告す る.

\section{対象}

対象は宏人会中央病院の透析患者で男 70 名, 女 54 名, 計 124 名である。うち入院患者は 11 名であった。

\section{方法}

アンケートでは排便の状況, 透析との関連, 下剤使用, 工夫と対策などについて，下記のようなアンケート表(表
1) を作成して質問を行った。下剤服用者と排便困難者 を併せて便秘群とし，その他は非便秘群とした。

\section{結果}

便秘群は 52 名で男 23 名, 女 29 名で全体の $42 \%$ を占 めた（表 2).

1 ) 昼夜別透析と便秘

外来透析患者 113 名をみると便秘は日中透析患者 58 名中 27 名 $(47 \%)$ ，女性 47 名中 24 名 $(51 \%)$ と日中透 析者や女性に多かった（表 3 ).

\section{2 ) 基礎疾患と便秘}

基礎疾患別に便秘群と非便秘群を検討した(表 4 )。糖 尿病性腎症では便秘群は 11 名中 8 名を占めた。一般に糖 尿病では自律神経障害から便秘を訴えることが多いが, 私達の例では $73 \%$ を占めた。囊胞腎は比較的尿量を保つ
このたび私達は，便秘（排便）に関してのアンケート調査 を行い, 今後皆さまがよりスムーズに，円滑な透析をうけ られるよう，力になりたいと考えております。よろしくご 協力のほどお願い致します。

$\begin{array}{lrrrr}\text { 名 } & \text { 前 } & & & \\ \text { 性 } & \text { 別 } & \text { 男 } & \text { 女 } & \text { 年齢 } \\ \text { HD年数 } & & \text { 年 } & \text { 職業 } & \end{array}$

8. 透析前は便秘がちでしたか

$$
\text { （はい，いいえ〔日〕おき） }
$$

9.透析前に下剤を飲んだことがありますか

(はい,いいえ)

10. 現在，便秘がちですか

(はい，いいえ)

〈はいの人だけ次からの質問に答えて下さい〉

11. 現在，下剤を飲んで毎日排便がありますか
(はい，いいえ〔
日おき）

1. 食欲はありますか(該当する項目に○をつけて下さい) (はい,いいえ)

2、排便は毎日ありますか

(はい,いいえ)

3. 排便の際は，スムーズに出ますか

(はい,いいえ)

4.いいえの人は，該当する項目に○をつけて下さい

(1)腹痛 (2)疼痛 (3)出血がある

(4)硬便 (5)残便感

5. 排便後スッキリしますか

(はい, いいえ)

6. 透析日と非透析日では排便に違いがありますか

(はい,いいえ)

はいの人はどちらかに○をつけて下さい

透析日（出やすい, 出にくい)

※その他に違いがありましたら記入して下さい

透析日（

非透析日 (

12. 下剤をどんなふうに飲んでいますか 毎日（錠）
(
日）おきに(
) 錠

13. 便秘で不快な思いをしたことがありますか (はい, いいえ)

はいの人は，該当する項目に○をつけて下さい

$\begin{array}{ll}\text { (1)腹満感 } & \text { (2)胸がムカムカする } \\ \text { (3)食欲がない } & \text { (4)腹痛 }\end{array}$

(5)その他

14. 便秘に対して，どんな工夫をしていますか，○をつけ て下さい
(1)生野菜を食べる
(2)果物を食べる
(3)牛乳を飲む
(4)運動をする
(5)市販されている薬を飲む
(6)コーヒーを飲む
(7)朝，空腹時に冷水を飲む
8)タバコを吸う

7. 便の質はどうですか
(1)硬い
(2)ふつう
(3)柔かい
(4)下痢
※ご協力有難うございました
(1)黒い (2)赤い (3)ふつう 


\begin{tabular}{r|l}
\hline 調査対象患者 & 124 名 \\
男 & 70 名 \\
女 & 54 名 \\
便秘群 & 52 名 $(42 \%)$ \\
男 & 23 名 \\
女 & 29 名 \\
\hline
\end{tabular}

表 2 透析患者と便秘

\begin{tabular}{c|c|c|c}
\hline & 男性 & 女性 & 計 \\
\hline 日中透析 & $7 / 18(39 \%)$ & $20 / 40(50 \%)$ & $27 / 58(47 \%)$ \\
夜間透析 & $14 / 48(29 \%)$ & $4 / 7(57 \%)$ & $18 / 55(33 \%)$ \\
\hline 計 & $21 / 66(32 \%)$ & $24 / 47(51 \%)$ & $45 / 113(40 \%)$ \\
\hline
\end{tabular}

表 3 外来透析患者 113 名と便秘患者（45 名）

\begin{tabular}{|c|c|c|c|}
\hline 基礎疾患 & 便 秘 群 & 非便秘群 & 計 \\
\hline 慢性系球体腎炎 & 38 & 49 & 87 \\
\hline 糖尿病性腎症 & 8 & 3 & 11 \\
\hline 妊 娠 中 毒 症 & 3 & 7 & 10 \\
\hline ネフローゼ & 1 & 3 & 4 \\
\hline の う 胞 腎 & 0 & 3 & 3 \\
\hline 慢性腎孟腎炎 & 0 & 3 & 3 \\
\hline 腎結 核 & 1 & 1 & 2 \\
\hline 腎＜wide>結 & 1 & 1 & 2 \\
\hline 痛＼cjkstart風 & 0 & 1 & 1 \\
\hline \multirow[t]{2}{*}{$\mathrm{S}$} & 0 & 1 & 1 \\
\hline & & & 124 \\
\hline
\end{tabular}

表 4 血液透析患者と便秘

\begin{tabular}{ccc}
\hline \multicolumn{3}{c}{ 問: 排便は毎日ありますか } \\
は & いいえ \\
便 秘 群 & 27 & 25 \\
非便秘群 & 69 & 3 \\
\hline 問：排便はスムーズにありますか \\
便 秘 群 & 21 & 31 \\
非便秘群 & 68 & 4 \\
\hline
\end{tabular}

問：排便後はスッキリしますか

$$
\text { はいいいえ }
$$

便秘群 $36 \quad 16$

非便秘群 $64 \quad 8$

表 5 透析患者の排便状況について

ことが多いが，囊胞腎では便秘患者はみられなかった。 囊胞腎以外においても比較的尿量を保ち, 週 2 回透析で 維持されている人は 2 名いたが，便秘患者はみられな かった.

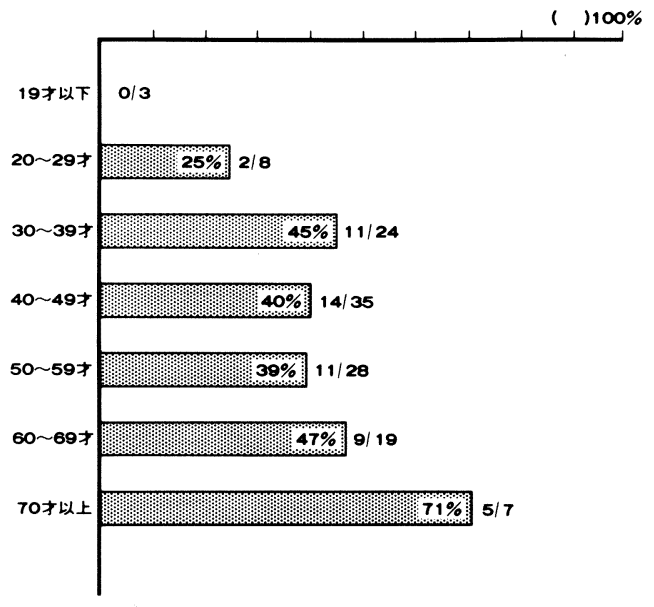

図 1 便秘患者の年齢別検討

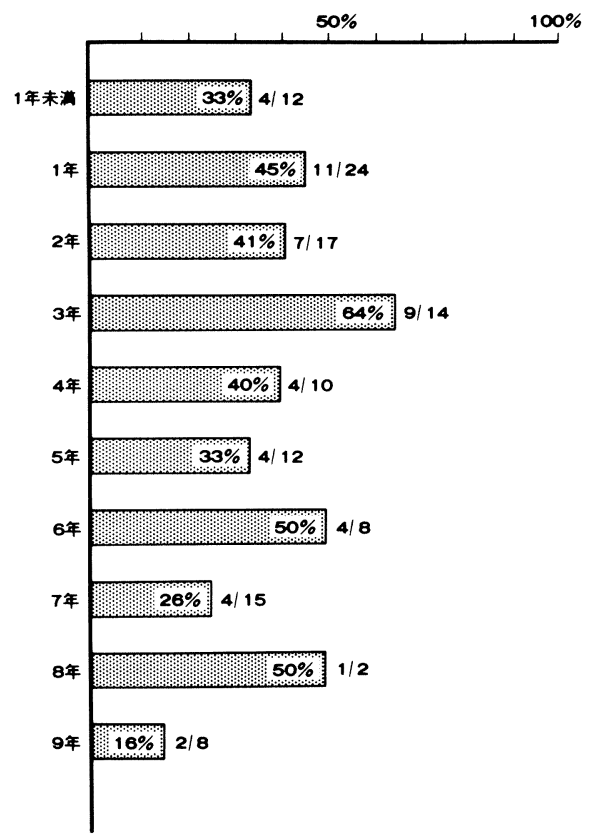

図 2 便秘患者と透析年数

3 ）透析患者と排便状況

排便状況の調査では排便は毎日ありますか, スムーズ に出ますか, 排便後スッキリしますかの質問に対して, 非便秘群はほとんど「はい」と答えているが，便秘群で は下剂服用により半数の人は毎日排便があるものの, 31 名の人が排便時スムーズに出ず, 痔痛, 出血, 残便感な どを伴っていた（表 5 ).

4 ) 年歯命と便秘の関係

年齢別にみると 30 歳未満でやや低率であるが, 各年代 とも $40 \%$ 前後に便秘者がみられている.しかし 60 歳以 
上の高齢者では 26 名中 14 名, 70 歳以上では 7 名中 5 名 （71\%）が便秘患者であった（図 1).

5 ) 透析年数と便秘との関係

透析年数別に比較すると, 図 2 のごとく透析年数と便 秘との間には関連がなかった。 7 年以上の長期透析患者
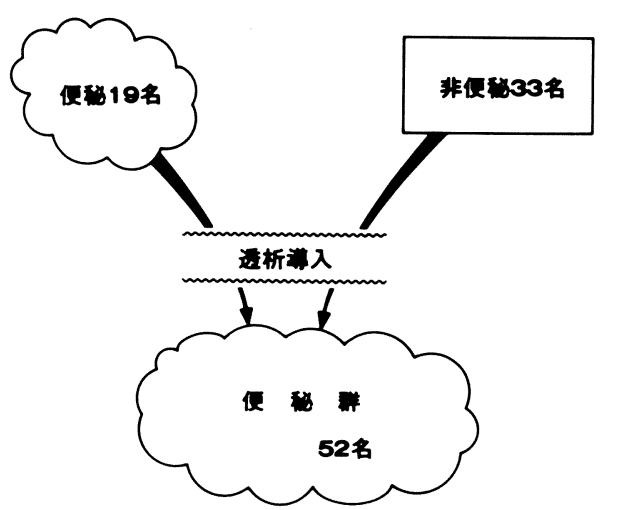

図 3 便秘群 52 名の透析導入前との比較
25 名中便秘者は 7 名と少なかったのが特徴的であった。

6 ) 透析導入と便秘の関係

便秘群 52 名の透析導入前との排便状態の比較をして みると, 導入前から便秘であったと答えた人は 19 名で, そのうち 10 名は導入後なお一層増悪したと答えている. 33 名が透析開始後に便秘になっていた。しかし導入前は 便秘傾向であったが，透析開始とともに改善したのが 3 名あった（図 3 ）。

7 ) 便秘患者の透析日と非透析日の排便の比較

外来透析患者の便秘群 45 名について, 透析日と非透析 日の排便の違いを比較してみた。非透析日より透析日の

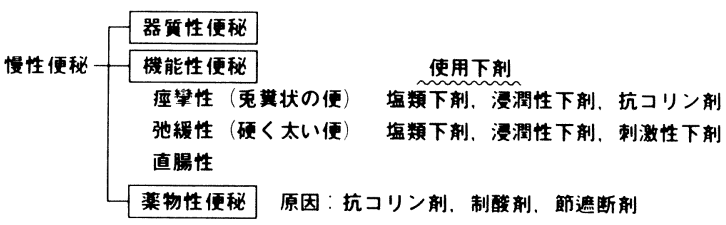

図 4 慢性便秘の分類と下剤

\begin{tabular}{c|c|c|c|c}
\hline & 透析日 > 非透析日 & 透析日 = 非透析日 & 透析日 <非透析日 & 計 \\
\hline 日中透析患者 & 9 & 15 & 3 & 27 \\
夜間透析患者 & 9 & 8 & 1 & 18 \\
\hline 計 & 18 & 23 & 4 & 45 \\
\hline
\end{tabular}

表 6 便秘群 (外来透析患者) の透析日と非透析日の排便の違い

\begin{tabular}{cc|c|c|c|c|c|c}
\hline & & 1 錠 & 2 錠 & 3 錠 & 4 錠 & 6 錠 & 8 錠 \\
\hline $\begin{array}{c}\text { 刺激性下剂 } \\
\text { (プルセニド) }\end{array}$ & 毎日隔日 & 1 & 7 & 4 & 2 & 3 & 1 \\
\hline 浸潤性下剂 & 毎日 & 1 & 4 & 1 & & 1 & \\
(ソルベン) & 隔日 & & 2 & 1 & & & \\
\hline
\end{tabular}

表 7 下剂服薬状況

\begin{tabular}{cc|c|c}
\hline 服薬量 & 便秘群 & 非便秘群 \\
\hline 0 & 錠 & 3 & 2 \\
2 & 錠 & - & 1 \\
3 & 錠 & 18 & 23 \\
4 & 錠 & 2 & 3 \\
6 & 錠 & 12 & 28 \\
7 & 錠 & 1 & - \\
8 & 錠 & - & 3 \\
9 & 錠 & 5 & 5 \\
12 錠 & 4 & 2 \\
\hline \multicolumn{2}{|c|}{} & 45 & 68 \\
\hline
\end{tabular}

表 8 水酸化アルミニウムゲルと便秘 （外来患者 113 名） 1 錠 $0.5 \mathrm{~g}$
1. 透析中の排便に対しての精神的不安感

2. 便秘のために体重が増加するとの考え

3. 便秘による痔, 排便痛への恐れ

表 9 透析患者の排便についての考え方の特徵

1. 腹部マッサージ

2 . 右足裹の指圧

3. 早く目醒めて生活を開始する（全身運動をする）

4. 早朝に冷たい牛乳または冷水を飲む（体重に注意し て)

5. 便意がなくともトイレに行き排便するように努力す る（特に朝食後がよい）

6. 繊維性食品の多食とバランスのとれた食生活をする

7. 下剂の効果的服用

8. その他アロエ（植物）服用

表 10 便秘の解消法と対策 
1．仰臥位にてやすみ、両膝を軽く立てる。

2.両手を臍から下にさげて、のの字を書きながら臍の中央で円を描きながら

30〜50回位い続ける。(腹部をあたためながらもも)

3 . 臍から両側に $4 \mathrm{~cm}$ 位い離机た場所を両手で圧迫して $2 \sim 3$ 秒位いして力を 抜く指圧法在20回位い続ける。

4. 臍の下 $2 \mathrm{~cm}$ 位のところを両手の指先を重权腹部を指圧する事を10回位い続 ける。

以上の事を連続して行う。就寝前に行う。

2 .

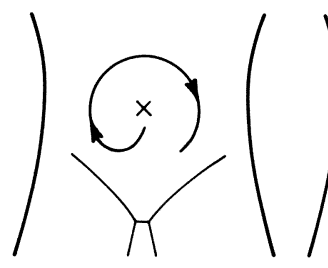

3.

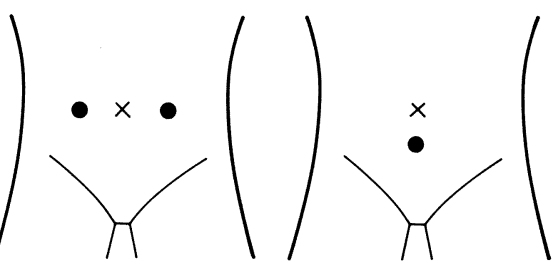

有足寒の指圧

右足が弱ると便秘、ガス発生などがある。

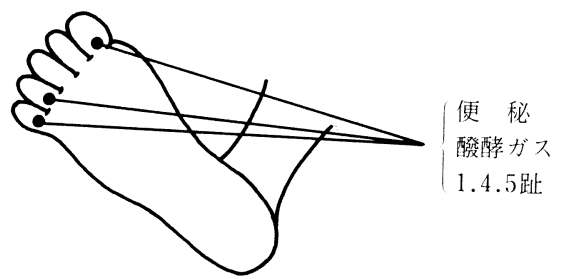

図 5 腹部マッサージおよび指圧による便秘の軽減法

朝の方が楽に出やすいと答えている人が 18 名と多く 40\%を占めた。これは, 透析後は除水により逆に脱水傾 向になるため, 透析の翌日は排便しにくいのではないか と考えた(表 6 )。表 6 においては，透析日の方が楽に排 便できる場合を透析日 $>$ 非透析日，逆の場合を透析日 $<$ 非透析日で示した。

8) 下剤服薬状況

使用薬剤はアントラキノン誘導体（センノシド，商品 名プレセニド)が最も多く 27 名に使用され, 毎日 $2 \sim 3$ 錠の人が多く 4 錠以上と常用量を越えている人が 6 名み られた。また，浸潤性下凬 (Dioctly sodium sulfosuccinate 〈DSS, 商品名ソルベン) は, 12 名が使用し 1 名 は 6 錠も使用していた（表 7 ）。

9 ) 水酸化アルミニウムゲルと便秘の関係

高燐血症対策として用いているアルミゲル投与量と便 秘の関係を検討したが，大量服用者でも便秘を来さない
者もあり，一定の傾向はなかった．しかし，アルミゲル が増加するとともに便は固くなるという人が多かった (表 8 ).

\section{考案}

血液透析の進歩により慢性腎不全患者の長期生存も可 能となったが, 種々の合併症の存在は透析患者の管理の 難しさをもたらしている．消化器合併症もそのうちのひ とつであり，なかでも便秘は日常的な患者の訴えにもか かわらず，下剤の使用のみに頼ることが多く，十分検討 されてはいない.

今回の調査により, 便秘群は実に $42 \%$ を占めた。後藤 ${ }^{3)}$ らは外来での慢性便秘患者は, 総数の 7 \%前後であった と報告しているが，これと比較するとかなりの高頻度で あるといえる. 男女比では後藤らと同様に女性に多かっ た。

図 4 は慢性便秘の分類と使用下剤を示したものであ 
る. 機能性便秘のうち, 痙攣性便秘は鬼䔬状の便のこと が多く，塩類下剂や浸潤性下剂の使用が，また弛緩性便 秘は硬く太い便のことが多く，塩類下剤や刺激性下剤の 使用が一般的である。しかし慢性腎不全患者ではマグネ シウムなどの微量元素の蓄積の問題から，塩類下剤を使 用することはない2). 便秘群の排便性状はほとんどが鬼 粪状であり，慢性便秘の分類からすると痙卛性便秘とな

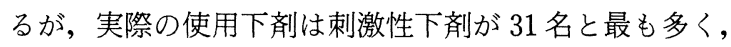
副作用もなく効果的であった。しかし下殽は長期連用に より効果の減少がみられ, 服薬量の増加傾向がみられた。

今回の調査に際して数多くの患者は，透析中に排便を 催すと困るので，どうしても透析日の朝に十分排便した いと訴えていた。また便秘のために体重が増加してしま

\section{食品の瀻維について}

便秘の食事療法の基本は高残渣食である。

正常の便通を保つには，一定量の不消化物を食べる必要 があり，その不消化残渣が大腸壁を刺激して蠕動運動を 高める。残渣成分の大部分は植物性瀻維であり, 日本人 の1日の繊維の摂取量は $5 \sim 6 \mathrm{~g}$ である.

繊維を多く取るための食事について

○バランスのよい食事をする（非便秘者はバランスのよ

い食事をとっている人が多い)

○極端に精製されたものは避ける

○野菜, 特に根菜類を積極的にとる

○海草類は繊維が多いがカリウムが非常に高いため注意 する

○カリウム值上昇がある場合は調理法の工夫をし，ゆで られる食品はゆでて攝取する
うという患者の不安や，便秘による帱痛や排便痛への恐 れを抱いているなど，便秘への精神的不安感が強いこと が判明した(表 9 )。それゆ光，下剤への依存性や耐性に より常用量を越える人もいた。

実際, 入院患者で排便前後での体重差をみてみると, ほとんどの場合は $100 \sim 200 \mathrm{~g}$ であるが，2〜3 日排便の ない時には $500 \mathrm{~g} に も$ 達することもあり, 便秘の時には 透析による除水量の設定に注意を要すると思われた。

以上の調査結果をふまえ, 私達は表 10 のような便秘解 消法のパンフレットを作成し, 患者が実際に経験して効 果があった腹部マッサージや指圧(図 5 ), 生活習慣の改 善等を指導した.

適度の運動により血液循環がよくなり, 下部消化管の

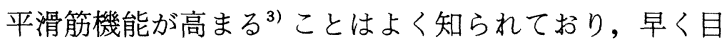
醒めて生活を始めるように指導した。また朝食後の排便 習慣 ${ }^{3}$ をつけるため, 早朝に冷たい牛乳または冷水を飲 むこと，また便意がなくてもトイレに行き排便を試みる よう指導した。これは大腸の大蠕動が朝食後に起きるこ とが多く, 朝食後の胃, 大腸反射が最もよく排便を促す からである ${ }^{3)}$.

食事面ではバランスの良い食事に重点をおき, 緎維の 多い食品とカリウム含有量の関係を表にし(表 12), 便通 によい繊維の多い食品 ${ }^{2,3)}$ を選び, 献立例(表 13)もあげ, 調理法等に工果しながら捸取するよう指導した（表 11). 繊維の多い食物（表 12）の摂取は大腸内での残渣を多く し, 蠕動を亢進させ腸内での停留時間を短くし, 便を軟 らかくする2)と言われている。

一方, 下剽多量服薬者で精神的影響が大きく, 下剤常

\begin{tabular}{|c|c|c|c|c|c|}
\hline 食 品 名 & ${ }^{\text {繊 }(\mathrm{g})^{\text {維 }}}$ & $\begin{array}{c}\text { カリウム } \\
(\mathrm{mg})\end{array}$ & 食 品 名 & ${ }^{\text {繊 }}(\mathrm{g})^{\text {維 }}$ & $\begin{array}{c}\text { カリウム } \\
(\mathrm{mg})\end{array}$ \\
\hline おか & 3.3 & 230 & ※ほうれん草 & 0.8 & 740 \\
\hline ※ごぼ & 1.4 & 330 & ※さつま芋 & 0.7 & 460 \\
\hline ※ぜん ん & 1.3 & 290 & ※たけのこ & 0.7 & 500 \\
\hline レ モ ン & 1.2 & 120 & な す & 0.7 & 220 \\
\hline ※ブロッコリー & 1.1 & 530 & キャべツ & 0.6 & 210 \\
\hline ※オ ク ラ & 1.0 & 320 & 大 根 & 0.6 & 240 \\
\hline ※力ボチ ヤ & 1.0 & 330 & ※れ んこん & 0.6 & 470 \\
\hline ※にんじん & 1.0 & 400 & ※ふ き & 0.6 & 310 \\
\hline ※さやいんげん & 0.9 & 280 & な & 0.6 & 140 \\
\hline ※か ぶ & 0.9 & 300 & ※里 & 0.5 & 610 \\
\hline ※に & 0.9 & 450 & ねぎ & 0.5 & 160 \\
\hline ※カリフラワー & 0.8 & 380 & り ん ご & 0.5 & 110 \\
\hline ね & 0.8 & 180 & ※じゃが芋 & 0.4 & 450 \\
\hline ※も & 0.8 & 240 & きゅうり & 0.4 & 210 \\
\hline ※京 & 0.8 & 340 & ト $マ$ ト & 0.4 & 230 \\
\hline ※せ & 0.8 & 400 & かき（果物） & 0.4 & 170 \\
\hline
\end{tabular}

表 12 繊維含量の多い食品とカリウムとの関係 


\begin{tabular}{|c|c|c|}
\hline 献 立 & 食 品 名 & 数 量 \\
\hline \multirow[t]{3}{*}{ トースト } & 食パン & 100 \\
\hline & マーガリン & 10 \\
\hline & ジャム & 20 \\
\hline \multirow[t]{5}{*}{ 洋風いり卵 } & 卵 & 50 \\
\hline & 牛乳 & 20 \\
\hline & 塩 & 0.3 \\
\hline & こしょう & 少々 \\
\hline & & 3 \\
\hline \multirow[t]{6}{*}{ サラダ } & キャベツ & 70 \\
\hline & サヤエンドウ & 15 \\
\hline & トマト & 50 \\
\hline & ドレッシング & $10 \sim 15$ \\
\hline & 塩 & 1.0 \\
\hline & こしょう & 少々 \\
\hline 牛乳 & & 100 \\
\hline \multirow[t]{7}{*}{ チキンライス } & ごはん & 160 \\
\hline & とり肉 & 40 \\
\hline & 人参 & 20 \\
\hline & 玉ねぎ & 20 \\
\hline & ピューレー & 20 \\
\hline & 油 ～～～～～～～ & 10 \\
\hline & 塩 & 1.5 \\
\hline \multirow[t]{3}{*}{ スープ } & トウフ & 50 \\
\hline & たけのこ & 10 \\
\hline & ワカメ & $2(15)$ \\
\hline & だし汁 & 100 \\
\hline & & 1.8 \\
\hline & こしょう & 少々 \\
\hline & 白ごま & 1 \\
\hline \multirow[t]{3}{*}{ 重ね煮 } & サツマ芋 & 70 \\
\hline & りんご & 50 \\
\hline & さとう & 6 \\
\hline $\begin{array}{ll}\text { 米 } & \text { 飯 } \\
\text { 刺 } & \text { 身 }\end{array}$ & ごはん & 200 \\
\hline \multirow{5}{*}{ 则 身 } & マグロ & 50 \\
\hline & きゅうり & 20 \\
\hline & ワサビ & 3 \\
\hline & しょうゆ & 少 \\
\hline & 大 根 & 40 \\
\hline \multirow[t]{4}{*}{ おろしあえ } & とり肉 & 30 \\
\hline & サヤエンドウ & 10 \\
\hline & レモン汁 & 少々 \\
\hline & 生揚 & 80 \\
\hline \multirow[t]{3}{*}{ たき合せ } & 小松菜 & 60 \\
\hline & しょうゆ & 6 \\
\hline & さとう & 4 \\
\hline \multirow[t]{3}{*}{ ヨーグルトあえ } & クんご & 50 \\
\hline & さとう & 5 \\
\hline & プレーンヨーグルト & 90 \\
\hline 間食 みかん & & 100 \\
\hline
\end{tabular}

\begin{tabular}{lrll} 
栄養量 & & & \\
エネルギー & $1,980 \mathrm{kcal}$ & 食品使用量 \\
水 分 & $1,340 \mathrm{~g}$ & 果 物 $200 \mathrm{~g}$ \\
蛋白質 & $80 \mathrm{~g}$ & 野 菜 $300 \mathrm{~g}$ \\
緎 維 & $4.2 \mathrm{~g}$ & 芋 類 & $70 \mathrm{~g}$ \\
カリウム & $2,440 \mathrm{mg}$ & & \\
$\mathrm{NaCl}$ & $7.3 \mathrm{~g}$ & & \\
\hline \multicolumn{5}{c}{13 献 立 例 }
\end{tabular}

用者となっていると思われる患者 6 名に対しては, 偽 薬2)を含めて処方し, 実際服薬量を減量したが, なんら排 便状況の悪化はみられず，良好な排便を保つことができ た。

以上のような試みを行った結果, 下剂から離脱できた 人が 13 名，減量できた人が 21 名もあった。

太田 ${ }^{1)}$ らは透析患者では消化管の運動障害があり, そ れは自律神経系のノイロパチー, および消化管の循環障 害によるものであり, 特に透析中にその影響が強くでる ものと推測している. 透析患者の便秘は太田らが言うご とく, 透析患者特有の運動機能の低下に加え, 除水によ る便の硬化, 制酸剤, イオン交換樹脂などの薬物の影響, 下剤の長期使用, 精神的原因など複合的要因の存在が考 えられる。それゆえ, 下剤の安易な使用に頼らず, 私達 の行った指導対策などの試みが大切と思われる。

近年，透析患者も高齢者が増え，それとともに透析患 者の老人の慢性便秘が重要な問題となってくると思われ る.老人では体力低下が排便困難をもたらし，ますます 食欲不振がおき食物摂取量が減少し, そのためさらに, 体力低下に陥るという悪循環がおきるからである31.こ の点からも, 透析患者の消化管運動機能の検討が重要と 思われる。

おわりに

血液透析患者の排便状況および下剂服用について調査 を行ったが, 便秘群は 124 名中 52 名, $42 \%$ 占めた. 透 析開始とともに便秘に陥った患者が多く, やはり水分制 限および除水等の影響が大きいものと思われた。下剤は 刺激性下剤の服薬者が多く実際効果的であった. しかし 透析患者では, 排便に対してかなりの精神的不安感を抱 いており, 下剤への依存性, 習慣性がみられた。常用量 を越す人に対し偽薬を処方することにより, 下剂の減量 が可能であった。

便秘対策として,社会活動の勧めおよび生活指導, マッ サージや指圧の試み, 繊維性食品の摄取の指導が重要で あった。下剤使用は慎重に行い, 使用の際には毎日では なく排便しやすい透析日の前夜に飲むとか, 多剤併用と かの工夫が必要と思われた。

\section{文献}

1）太田和夫：消化管の合併症, 透析患者の診かた考え 方. 太田和夫, 他, 編集, p. 65, 南江堂, 1979 .

2) Stone, W. J. : Therapy of constipation in patients with chronic renal failure. Dial. Transpl. 6 (7) : 30, 1977.

3）後藤由夫, 中目千之：慢性便秘. 医薬ジャーナル, $19: 190,1983$ 